\title{
ISLAM, LOCAL "STRONGMEN", AND MULTI-TRACK DIPLOMACIES IN BUILDING RELIGIOUS HARMONY IN PAPUA
}

\author{
Idrus al Hamid | IAIN Fattahul Muluk Papua - Indonesia \\ idrus@iainpapua.ac.id
}

\begin{abstract}
This paper comes with new perspectives in understanding the dynamics of Papuan society in relation to Islam and local "strongman", especially in the frame of religious harmony. It enriches the research of how national political contestation affects the dynamics of religious harmony in Jayapura, Papua, through three important distinctions: first, socio-anthropological studies on how Islam and Muslim groups dynamics relate to the transformation of the society; second, the analysis of Islamic religious leaders' roles in building religious harmony through local "strongman" perspective; third, the reframing of efforts in creating harmony in national, religious, and social life with multi-track diplomacies approach. This research with those three focuses results in a final lexicology: "building values/cultures does not mean tearing down entirely the existing ones; creating religious harmony does not need to eliminate teachings of any religions". In other words, the process of assimilation, acculturation, and segregation at the most micro-level interactions, even individuals, has always to be recognized as an effort to create cultural amalgamation. In that way, local leaders of indigenous Papuans, bossism, and those who take refuge in cultural-structural organizations would never feel threatened with each other.
\end{abstract}

Keywords: Islam, local strongman, culture, religious harmony

\section{Introduction}

Any identity contestation on a global, national and regional scale, possibly makes a paradigm shift in Papuan society, especially in Jayapura, because they have a very striking difference with the 
conditions of Jakarta as the national capital, and several supporting cities. Later, if there is dynamics of identity that is displayed and exhibited in national political contestation, the people in Papua are inspired to emulate it at the local level of Jayapura. As a simple example, they often carry out demonstrations to make regional regulations based on Christian religious values - as Christianity is the major religion in Jayapura. ${ }^{1}$ Therefore, this article might be more inclined to look at the strengths of local leaders who make direct dialectics on community groups in Jayapura, at this time. Their existence could be a reinforcement of the effort to maintain the peaceful of Republic of Indonesia, or vice versa. They play their social and political role to form different opinions.

Within the framework of socio-political thinking, sociologists suspect that in the space of freedom there must be local "strongmen", who can help strengthen the wishes of the central government to build a good democracy. In the terminology of J. Harrits K. Stokke et.al, it is called bossism in an organization. It refers to those who do not include in the structural authority, but have cultural influence. He stated that in social spaces it forms into mafias, bosses of large companies, and tribal chiefs (with lineage). ${ }^{2}$ According to John T. Sidel analysis, there is a tendency that bossism (the capitalists), especially in Southeast Asian societies (such as Thailand and Philippines), represent local "strongmen" in shaping and building patterns of interaction between democracy and society. A slightly different thing, according to him, is what can be seen in Indonesia. Here, the role of ethnical groups, lineages, and religious entities is more dominant than those who have strong capital. ${ }^{3}$ M. Syaeful Bahar, in his dissertation, stated that the pattern of interaction of local "strongmen" in the consolidation of democracy in East Java especially in Bondowoso was divided into two

\footnotetext{
1 Idrus al Hamid "Politik Identitas, Pluralitas Agama, dan Implikasinya terhadap Keberagamaan Masyarakat di Jayapura, Papua" (Paper presented at National Seminar in IAIN Papua, 2018). See also Idrus al Hamid, "Political Identity, Culture of Religious Plurality, and Implication in interaction of Jayapura Partnership," International Journal of Management and Administrative Sciences, 5, 10 (2018), pp. 18-29.

2 J. Harriss, K. Stoke and Olle Tornquist (eds), Politicizing Democracy: The New Local Politics of Democratization (London: Springer, 2004), p. 72.

3 John T. Sidel "Bossism and Democracy in the Philippine, Thailand, and Indonesia; Towards an Alternative Framework for Study of Local Strongman," Harriss, Stoke and Tomquist (eds), Politicizing Democracy, p. 16.
} 
models, namely bejingan ${ }^{4}$ and kyai (religious leaders). ${ }^{5}$ He then added that the pattern of these two local "strongmen" could be mutualistic towards the consolidation of democracy, if the methods and political strategies used to win a candidate were carried out elegantly. But on the contrary, the consolidation of democracy is difficult to build, if they contest with one another. ${ }^{6}$

Apart from the local "strongman"s postulation framed with political science above, the position of this paper is intended to be a complement to studies on the same scientific contestation, or to be 'against methods and evidence' to negate their products of study. ${ }^{7}$ I

4 M. Saeful Bahar explains how the word bejingan (in Madurese language) differs in meaning with the word bajing (in Javanese). Bejingan in political power contestation more often refers to someone who would bet his/her treasure, physical body, and strength on one of the candidates to win an election. Also, the word bejingan could refer to a former thug, murderer, or criminal feared by the surrounding society. As a result, according to Bahar, it is understandable if the word bejingan is put side by side with kyai (religious figure) with the quality of personality (charisma and influence) to ask others for choosing a particular candidate. See M. Saeful Bahar, "Pola Interaksi Kyai-Bejingan dalam Pembangunan Demokrasi di Indonesia: Studi terhadap Local Strongman dalam Pilkades di Kabupaten Bondowoso Jawa Timur (Unpublished Dissertation, Airlangga University, Surabaya, 2017).

5 In addition to widening the framework of thinking about bejingan, Saeful Bahar's research also uniquely explain the relation of kyai and bejingan in the context of subsequent-formed socio-political life pattern and local contestation. The first type of relation between kyai and bejingan is cooperative-mutualistic. This could happen when kyai and bejingan have the same candidate, and work together to win him/her in an election. The second type of their relation is formed when they have a different choice of candidate. In this situation, kyai and bejingan are opposite to each other. However, bejingan is more likely to win the contestation due to more capital (money). Moreover, the villagers tend to defend their assets (including the sense of security) by not opposing the bejingan. The third relation is called kyai-bejingan. I consider this relation pattern as the most complicated relation to describe. One certain thing is that kyaibejingan means a kyai who 'nurtures' bejingans by applying the approach of cultural assimilation. It also could refer to a former bejingan kyai (a repentant bejingan). In political contestation, kyai-bejingan always win the local political battle; and on behalf of the democracy development, kyai-bejingan has the strong influence over the society. See Ibid.

6 Ibid., p. 34

7 I surely believe that observing political issues of Papua through this perspective will result in uniqueness, however, Papuan society in its political standing do not always consider economic, religious, and tradition factor. It also often uses the strategy of leaders, businessmen, and other entities optimization by giving them specific calls/names. In accordance with that, the traditional leaders in Papua become the key figures to filtering political issues and defining the chosen path of life. 
just want to borrow and use it as a framework for reading the dynamics of religiosity in Jayapura-Papua. The use of this way of thinking seems appropriate, in my opinion, for several socioanthropological reasons: first, Papuan society is very rich in culture and they protect its authenticity in daily life. For this reason, they use a method of appointing traditional leaders who must be responsible to their groups. Secondly, Papua has natural wealth and natural economic values over which possibly drive a battle of various interests and determine the direction of change in Papuan society. This subsequently affects the relations of capital owners and the social behavior of Papuan society, especially of the capital city Jayapura. Thirdly, Papua societies strongly uphold their religious values, and apply them within their existing local culture. In this context, religious leaders then also have a role in generating dynamics in the lives of Papuan society. Fourth, of course, structural power and political dynamics will also greatly affect Papuan society indirectly. ${ }^{8}$

From a glance of this fact, I systematize this writing into several important points: first, cultural-interaction and religious harmony in Jayapura-Papua; second, portray of Islam and Muslim Groups in Jayapura Papua; third, religious conflicts and local "strongmen" roles, including Islamic religious leaders, in Papua; fourth, diversification of cultural interests and the role of local "strongmen" in Jayapura-Papua. From these four points of discussion, the ideal interaction patterns of capital owners, religious and traditional leaders, and structural political power in Papua will be produced in terms of building a new culturebased civilization in Jayapura-Papua. Because some of the facts in this paper are subjective-phenomenological as I am a Papuan, ethnographic terminology mentioned directly by the informant of this research is purposely allowed to maintain the authenticity of the meaning. This article is limited to discuss the dynamics of social culture especially in Jayapura city.

\footnotetext{
8 Musa Yan Jouwe, Eka Afnan Troena and Margono Setiawan, "Pengaruh Peran Tiga Tungku (Tokoh Pemerintah, Tokoh Adat, dan Tokoh Agama), dalam Gaya Kepemimpinan terhadap Kinerja Aparat Kampung di Kota Jayapura," Jurnal Aplikasi Manajemen, 9, 1 (2011), p. 242.
} 


\section{Socio-cultural Interactions and Muslims' Share of Religious Harmony in Papua}

Discussing about Papua with the perspective of cultural shift and religious groups change as they come up to the surface and are known by many people is not easy. It is caused by the framing to the observers' brains that has been clashed initially with destructive logos, for example, inter-tribal brawls in Papua, ${ }^{9}$ Papuan society demonstrations against Freeport, ${ }^{10}$ as well as arrested figures of the Free Papua Movement, ${ }^{11}$ and religious conflicts like rejection of the building house of worship, ${ }^{12}$ or burning a mosque in Tolikara, ${ }^{13}$ and other conflicts due to the shift of Muslims' religious attitude in Papua. ${ }^{14}$ In building these logos, all elements seem to make a significant contribution. It starts from the central government by setting Papua as a special autonomous region, along with mass and electronics media with continuous show of conflicts in Papua, and researchers and academics portraying Papua from various impacts of economic, cultural and socio-political colonialism. Therefore, as someone who lives and grew up in Papua, I want to clarify first what and how cultural transformation, economic expansion of the elite group to Papua, and religious groups in Jayapura, Papua, interact each other.

9 See "Perang Suku di Papua" https://nasional.tempo.co/read/1132282/kapolribenarkan-terjadi-perang-suku-di-papua-dua-polisi-terluka (accessed on 2 December 2018)

10 See "Demonstrasi Pekerja Freeport" https://economy.okezone.com/read/ 2018/08/17/320/1937942/demo-eks-pekerja-freeport-bagaimana-kisah-sebenarnya (accessed on 2 December 2018)

${ }^{11}$ See "Penangkapan Tokoh Gerakan Papua Merdeka" https://www.bbc.com/ indonesia/indonesia-46454974 (accessed on 2 December 2018)

12 See in dept report of tirto.id "Problems of Minority Religions: Difficult to Establish Houses of Worship" https://tirto.id/problem-umat-agama-minoritas-susahmendirikan-rumah-ibadah-dJeE (accessed on 18 April 2018)

13 See "Pembakaran Masjid di Papua" https://www.republika.co.id/berita/ nasional/hukum/15/07/17/nrmprs-ini-kronologis-pembakaran-masjid-di-tolikara (accessed on 18 April 2018)

14 See "Penolakan terhadap Kelompok Umar di Papua" https://www.youtube.com/ watch?v $=$ Wm6aTIQCO40 $($ accessed on 18 April 2018) 
In the history of Papuan society, with the absence of political consideration, ${ }^{15}$ Andrew J. Marshall said that there are three processes of groups formation in Papua: First, kinship (originating from certain clans or descendants) as was the earliest society in America. He said there were several clans here, such as Lha, Waropen, Senggi, and MarindAnim; Second, the same descent but in the form of ethnicity, for example, Mairasi, Mimika, Hattam-Manikion, Asmat, Kimam, and East Coast Sarmi; Third, omaha (a system that uses differential terms for the maternal process), for example, Meybrat, Aunyu and Muyu. ${ }^{16}$ Today, from my point of view, the social groups mentioned earlier still have influence on the society, at least around their own territory. The richness of ethnic, language, tribes, and custom tradition indeed is still well preserved in Jayapura, Papua. Still based on my subjective view, these groups of society can still be seen in ruling the traditional markets, certain religious activities, or in professional associations, according to what their lineage is grounded. In such position, whether acknowledged or not, they have one strong (or elder) person to give consideration in any important actions and activities of the respective communal group. ${ }^{17}$

15 Studies in merely political perspective, in my opinion, tend to be forced to simplify the portrait of various social-cultures in Jayapura. They put the Papuan society into several big groups that is just seen on the surface, assuming that there has been a collective transformation from primitive paradigm to more modern one. In fact, the existence of the cultural groups is continuously preserved .... I want to prove that a descent of Meybat, for example, has different views toward some policies implemented in Jayapura. Yet, due to the lack of bases, they chose not to express their opinion. A. J. Marshall illustrated the political condition in Papua as follows: "...The major differences between political systems are the geographical extent of their power and their political orientations... in the big man political system the leadership position is based on individual achievement... The kingdom system is primarily characterized by ascribed political status or inherited position... The Ondoafi system (in Papuan political context, pen) is similar to the kingdom system in that leadership positions are inherited and traditional bureaucracies are utilized. However, the Ondoafi system differs from the kingdom system in its geographic range of power and political orientation. The power of an Ondoafi leader is limited to single village and unit of ethnical sub-group..." Representativeness in such political system, in my view, have largely reduced the dynamics of power and authority in a lineage knot. See A. J. Marshall and Bruce B. Beehler, The Ecology of Papua (Sydney: Periplus edition Ltd., 2007).

16 Ibid., p. xi.

17 Denny Eris Waimbo and Prapto Utomo, Dinamika Masyarakat Papua pada Era Otonomi Khusus (Jayapura: Universitas Cendrawasih Press, 2011), p. 3. 
The next concern is about the existence of religion in the Papuan society. Relating to religious population in Papua, Cahyo Pamungkas said as follows:

"The population of Papua Province (minus West Papua) in 2006 is 2,524,275 people. They embrace Christian (55\%), Catholics (30\%), Islam (14\%), Hindu (0.17\%) and Buddhist (0.39\%). The Muslim population in Papua generally is the migrant coming through transmigration policy and spontaneous migration. If the migrant in Papua, in 1971, is 4\% from total population of Papua, they become $35 \%$ in 2000. Fifteen years ago, $90 \%$ of Papua is native people. In 2003, cities and town in Papua are inhabited by migrant $(90 \%)$ where they dominate the economy trade, labor, transportation, and private offices, and other business." 18

The data above may have changed due to the increase of population in Papua and very intensive religious interactions among the Papuan society, especially in Jayapura. Data from the Central Statistics Agency stated that there were 16,105 Papuans who embrace Islam, 210,421 Protestant Christians, and 82,771 Catholic Christians. In Jayapura City, the proportion of religious followers is more balanced: 254,100 people in the city are Muslims, 283,493 are Protestant Christian, and 84,474 are Catholic Christian. ${ }^{19}$ In the context of religious harmony in Papua, the regent of Jayapura Mathius Awoitauw said that the government had built the zone of integrity to establish harmony among religious people in his regency. ${ }^{20}$ Meanwhile, the Governor of West Papua claimed that the interreligious harmony index of Papua rose to $72.84 \%$, indicating that there had been a positive increase in the level of the harmony than before. ${ }^{21}$

In the culture of Papuan Muslims, there are a large number of organizations that represent various Papuan Muslim groups. Majelis

18 Cahyo Pamungkas, "The Contestation of Muslim and Special Autonomy in Papua," Religio; Jurnal Studi Agama-Agama, 5, 1 (2015), p. 30.

19 Data of Papua BPS Office at 2016, https://papua.bps.go.id/ (accessed on 26 March 2018)

${ }^{20}$ See "Zona Kerukunan Beragama Kini ada di Jayapura" https://nasional. tempo.co/read/770572/jayapura-jadi-zona-integritas-kerukunan-beragama (accessed on 26 March 2018)

21 See "Indeks Kerukunan Umat Beragama di Papua Barat" http://www. satuharapan.com/read-detail/read/indeks-kerukunan-umat-beragama-di-papua-barat7284-persen (accessed on 26 March 2018) 
Muslim Papua (Papua Muslim Council) is one of the institutions that provide religious views, in addition to other structural entities such as the Majelis Ulama Indonesia (Indonesian Ulama Council) of Papua, and representative groups or branchs of national organizations such as Nahdlatul Ulama Papua and Muhammadiyah Papua. Musa Ramburu \& Surwandono said that:

"Majelis Muslim Papua had strategic role to consolidate Islam groups in Papua. The MMP establishment is more encouraged by the wishes of Muslim elite group communicated institutionally with local government. Although the first, MMP only intended as Muslim group meeting place, but in the journey changed to be organization or moving institution struggling for Muslim interest in Papua, Muslim interest before was struggled from the figures of Papuan council (MRP). In that institution, Muslim group had one representative only so that was not enough to accommodate and struggle Muslim group interest. MMP standing one of its main passions as institution for Papuan Muslim group who are from various ethnic and areas. They collected in MMP institution were not only Muslim from Papua, but also Muslim comer then living in Papua, in this matter was Muslim comer. MMP movement shift later involved politic in local level actually encouraged by various interests both in internal and external. In internal, MMP needed legitimation as organization becoming 'shared house' of Muslim groups which is from various backgrounds..."22

Concerning to other religious groups, Muh. As'ad stated that there are three components which are usually dominated by religious groups other than Islam, i.e. government, traditional entities, and special associations of several religions in Papua. In the united religious group in the Jayapura city are mentioned Persekutuan Gereja-Gereja Jayapura (PGJ), Majelis Agung Wali Gereja, Parisada Hindu Dharma, and Lembaga Umat Budha. ${ }^{23}$ However, these associations do not represent other different groups, for example, Gereja Kristen Injili di Tanah Papua (GKITP) and Gerakan Muda Kristen Jayapura. ${ }^{24}$

\footnotetext{
22 Musa Ramburu, Suwardono, Hasse J. and Ridho al Hamdi, "The Construction of Muslim Identity Post Special Autonomy; The Study of Majelis Muslim Papua Existence," Epistemé: Jurnal Pengembangan Ilmu Keislaman, 13, 2 (2018), p. 314.

23 Muh. As'ad "Kehidupan Keagamaan dan Budaya Masyarakat di Kota Jayapura Provinsi Papua," Jurnal al-Qalam, 20, 2 (2007), p. 90.

24 See "Dibalik Polemik Penolakan Menara Masjid di Papua," https://tirto.id/di-balikpolemik-penolakan-menara-masjid-di-papua-cGrd at accessed on 25 August 2018.
} 
Such a good contact of harmony can also be seen from the side of future generations in Jayapura society. The existing educational institutions apply education models by which the values of peace and harmony are practiced as the basis of Papuan society's life. A report from the Ministry of Religious Affairs of Jayapura illustrates that religion-based education is a right that must be affirm to all students according to their respective religions. Later on, Jayapura government and the central government established housing for Papuans who were Hindus and Buddhists. The objective of this is to let cultural assimilation to occur well in the environment where the young generation lives within, in terms of religious conditions and ethnicity issues. ${ }^{25}$ Sabara, in his research, also stated that several peace campaigns was also carried out by the Yayasan Pendidikan Islam (Islamic Education Foundation) of Papua in various forms, one of which was by dismissing the issue that the Islamization process carried out in Jayapura used radical and coercive methods. The presence of Islam in Jayapura still adheres to the values of tolerance, moderation, and respect encompassed substantively within the Islamic teaching itself. ${ }^{26}$

\section{Islam and Muslim Groups Dynamics in Jayapura}

It has been explained above anthropologically that there are several Islamic groups that have an important role in building, developing, and encouraging the Papuan society, especially in Jayapura, to be aware of and understand the differences that exist among them. Perhaps, it also needs to be understood that the Jayapura Muslims entity also has its own individual and group attribution in sociological and political terms among the Islamic community itself. Cahyo Pamungkas, for example, revealed contestation among Muslim-migrants and Muslim-indigenous Papuans (of Melanesian race - who embrace Islam), in terms of overtaking dominancy in Islamic institutions and organizations in Jayapura. $^{27}$

${ }^{25}$ Kantor Kementerian Wilayah Agama Provinsi Papua, Majalab Damai; Jembatan Hati Nurani Umat 16 (2017), p. 23

26 Nuruddin Sabara "Kiprah Setengah Abad Yayasan Pendidikan Islam (Yapis) Papua; Membangun Harmoni Beragama Melalui Dunia Pendidikan," al Qalam, 24, 1 (2018), p. 66.

27 Cahyo Pamungkas, "Muslim Papua dan Muslim Pendatang; Pertarungan Identitas Antara Ke-Indonesiaan dan Ke-Papua-an,” Kawistara Journal, 2, 22 (2016), pp. 225-324. 
He also revealed some of the social relations of Papuan Islamic groups as follows. The first one is Islamic organizations which have political-social relations, that is, the organizations recognized by the central or regional government, as well as getting access to its funding. Of this category, there are The Ulama Council of Indonesia (MUI), Islamic Education Foundation (YAPIS), The Indonesian Association of Muslim Intellectuals (ICMI), and The Muslim Council of Papua (MMP). The second is Islamic organizations which organize nationalscaled movements, and are accepted symbolically by the Papuan society. Of this category, there are Nahdlatul Ulama (NU) with its Islamic moderatism values, Muhammadiyah with its concern about education, and Hidayatullah. The third is Islamic-Political organizations in Papua, such as Assalam representing the Prosperous Justice Party (PKS) of Papua and the Indonesian Institute of Islamic Da'wah (LDII) related with the Golkar Party. The fourth is Islamic organizations that tend not to be accepted symbolically by the Papuan society, such as Hizb ut-Tahrir Indonesia (HTI) and the Islamic Defenders Front (FPI). ${ }^{28}$

Based on this pattern of relations, the tendency of Muslim individual's attitudes in Jayapura will be more moderate and peacefuloriented in interacting with one another. It is in line with the dominance of moderate Islamic organizations that would certainly affect the individual's attitude of Papuan society. As an example, the practical attitude (habitus) of MUI, MMP, Muhammadiyah, and Nahdlatul Ulama is to promote a peaceful and tolerant Islam towards the existing differences. Conversely, the non-Muslim community groups also accept the existence of these Islamic communities to encourage and strive for the development of Papuan cultures. Besides, the first concern of these organizations is organizing education in the society - not to impose certain ideologies or political interests. These Islamic organizations play a cultural role to improve the quality of human resources in Jayapura.

The description of the power contestation, as stated by Cahyo Pamungkas above, is not a true display of internal relations of Muslim groups in Jayapura. Such dynamics occurred like inside any other organizations. Even so, I also listened and observed that there were some government's 'policies' that tended to prioritize the indigenous

28 Ibid., p. 259. 
Papuan Muslims rather than the Muslim migrants in Jayapura, but it rarely happened as political adjustment. Once again, I would like to emphasize that strong solidarity and harmony within the Muslim community is intertwined very well; both among Islamic organizations (except the Islamic radical organization) and in community traditions, such as togetherness that is built on the rituals of Haij, maulidan (Prophet's birthday celebration) and other celebration in Islamic tradition.

These two aspects (moderate and inclusive) of the majority groups of Muslim community in Papua should have been manifested in social harmony. They could become transcendental supporting structure to the existing culture of Papuan society who indeed originally respects diversity. Based on the role and normative framework of thinking, the relationship among religious groups in Papua, especially in Jayapura city, is very well established. However, this potential condition of living in harmony has been restrained due to some conflicts. Although the pattern of mediation used by the government to accommodate the overall cultural, social, and religious values of the Papuan society is an entry point for the harmony and togetherness to be well managed, sometimes at the national level, media framing about the people of Papua remains unchanged and still relies on conflictual segmentation in the land of Papua. So, the question is, in a sociological and anthropological perspective, how the conflict ripples occur. In the next section, using a normative approach, I would like to explain how Muslims are involved in conflicts --between local or rural ethnicity, in political contestation, and in interaction with other religions-- and what the Islamic religious leaders' role in building peace is.

\section{Dealing with Religious Conflicts in Papua: Positioning Islamic Religious Leaders among Local "Strongmen"}

In the context of conflicts in Papua, especially in Jayapura, I would like to early state that not all of them source of political issues. Also, those are not specified merely to a kind of seizing or shifting power problem in the local societies. The identity conflicts in Jayapura are more often formed as a response to dynamics far beneath the Land of Cenderawasib. I am likely to agree with a statement of Abd. Mu'ti and Najib Burhani, that is:

"In Papua and West Papua provinces, where Christianity is a dominant religion, there were efforts by religious activists there to 
implement favoritism to Christianity by making kota Injili (city of Bible) and making local regulations that more inclined to support Christian mission. For political and diplomatic goal, i.e. Helsinki agreement, Aceh province has even become an "Islamic province" that implemented shari'a law, including wilayah hisbah or religious police. Wearing hijab becomes mandatory in that province, regardless religious affiliation of people there. Hudud is partly implemented for those who violate Islamic law. After Aceh and Papua, some Hindu people in Bali have tried to follow the step of these two provinces by proposing regulation that gives favoritism to Hinduism." 29

The statement above indicates that there are such phenomena in Jayapura that the people imitate the way others do in terms of developing their own identity, especially when it comes to the comparison between Aceh and Papua with their same status as special autonomous regions (daerah otonomi khusus) in Indonesia. Papuan society, anthropologically, have strong sense of belonging to the genuine of their daily life values, including the religion of the majority.

Another factor leading to religious conflict in Papua is the antagonism of some groups, in any other parts of the world, who justify their actions by the name of religion. J. Budi Hermawan stated that after $9 / 11$ tragedy in the United States, reactions of extremist inside the churches had also arisen. They expect there have been religious instability among the Papuan society's life. Moreover, some subsequently tragic events came after, such as Bali Bombing, Poso violence, and others which worsen the suspense among the Christians. This condition confirms the groups who want to defend their identity to tyrannize the minority in their daily life. ${ }^{30}$ It also affects the communal interaction amongst Papua intra-society. Religious plurality in Papua seems to form a kind of inter-religion contestation. In other words, the Christians feel that their religion is disturbed by the presence of other religions whose followers are conducting religious activities inside or around their territory.

29 A. Mu'ti and Najib Burhani "The Limits of Religious Freedom in Indonesia; With Reference to the First Pillar Ketuhanan Yang Maha Esa of Pancasila," Indonesian Journal of Islam and Moslem Societies, 9, 1 (2019), pp. 111-112.

30 J. Budi Hermawan, Gereja-Gereja di Papua; Menjadi Nabi di Tanah Sendiri (Jayapura; Sekretariat Keadilan dan Perdamaian Keuskupan Jayapura, 2002), p. 23. 
Currently, the contestation and antagonism of certain religious group in Jayapura have come to surface. In the context of contestation between Islam and the majority religion in Papua, for example, the Governor of Papua explicitly refuses any Islamic groups or movements that want to establish Islamic state, exhibit religious radicalism, and promote massive Islamization in some regions in Indonesia with nonacculturative approaches. ${ }^{31}$ It is as a response to the issue of Islamization that openly spoken up by Ridwan al Makassary by saying that Jayapura City is in on-going massive Islamization; Jayapura City has been surrounded by flags of Hizbut Tahrir Indonesia (HTI) and will become a part of Islamic group fight for expanding the religion and belief.

Based on my observation, the previously described phenomena have born wide restlessness among the local (native) people and Muslims in Papua. The existence of various religious groups that, in fact, take care of each other, build and make the Land of Cenderawasib great together, has been unfortunately disgraced by certain religious, social, and cultural activities running from outside Papua. Concerning this, I have also done a research on Jayapura society's responses to the current religious condition, relations constructed by religious groups in the society, and causes of why the Jayapura society can easily be provoked by religious issues expressed in public spaces.

Some religious leaders whom I interviewed in accordance with this context stated that there are at least four contributing factors in the Papuan society's harsh reaction to religious issues that could cause conflicts among the society itselfs. The first is difference in values and views toward them over different religions. ${ }^{32}$ Jayapura societies previously were very aware of various religions on their land; they could have good interaction without mentioning their religious identity. Hence, when there came a group of people (migrants) who put religious values before their cultural ones, a shock culture strokes the local societies. Furthermore, this indirectly led to a specific reaction from them to the new phenomenon.

The second is the emergence of new religious groups midst the society as a consequent effect of the extension of policies run by their

31 See the Officials Statement at "Papua menolak FPI dan HTI," https://www.papua.go.id/view-detail-berita-4426/papua-tolak-fpi-dan-hti.html) (accessed on 23 March 2018)

32 Interview with a Church Leader in August 2018. 
parent organization, at the local or national level. The third is the provocation by traditional or religious leaders to fight the new groups. The fourth is the closed space of dialogue between the two opposing groups because of the exclusiveness formed by the new-emerged ones. These new groups who are overreactive to the existing situation tend to close themselves for public interaction and unwillingly dialogue their anxiety and restlessness. This new "model" of life could widely erode the genuine pattern of Jayapura society's life; they actually are quite civilized to openly dialogue on such conflictive problem happening in their society. 33

As a determinant factor in dealing with the conflicting issues, the position of local "strongmen" of Jayapura should be discussed. Similar to those of other Papua regions in general ${ }^{34}$, the local "strongmen" of Jayapura may, anthropologically, come from traditional (tribal) leaders, religious leaders, and government administrative officers. Furthermore, in sociological perspective, there has been a shift of power when businessmen (capital owners), politicians, and other elements of goverment (such as police) exert their influence on the society of Jayapura that is relatively more modern than other Papua regions.

The question is how the local "strongmen" such as government, traditional leaders, and religious leaders play their roles in minimizing the conflict, aside from the use of their political force? The approaches used by the local "strongmen" are more cultural and social oriented and based on the characteristic of the society, especially in Jayapura. Theoretically, J. Budi Setiawan stated that: the majority Christians in Papua should be "Nabi Sendiri" (a self-prophet) in their own land. The term of "Nabi Sendiri" refers to prophetic values that should be applied among Papua societies. He then clarifies the definition of being a "Nabi Sendiri" as: (1), building peaceful and anti-violent culture as the main value of the Papua leader and people since the beginning of the Independence Day; (2) developing the values of inter-religious and inter-cultural dialogue; (3) upholding justice and truth; (4) evaluating projects collectively; (5) criticizing religious politicization; and (6) upgrading the quality of life. ${ }^{35}$

33 Interview with Hindu-Buddhist Leader in August 2018.

34 See Marshall and Beehler, The Ecology of Papua.

35 Hermawan, Gereja-Gereja di Papua; Menjadi Nabi di Tanah Sendiri, p. 25. 
In the context of Islam, Nino Viartasiwi remarked that a group should be consistently in line with the consensus that had been agreed together, i.e. "Muslim communities of Papua are indigenous Papuans and Muslim individuals or groups who are Muslims and live and settle in the land of Papua". By being consistent with what have been chosen as Muslim community in Papuan society, they would not be regarded as a threat against any other groups or communities that have been long settled in Papua before. In addition, it will also affect to the roles they can carry out. In term of the roles, Nino Viartasiwi stated:

"In a political antagonism leading to violence of Papua, the unlikely position of the Muslim Papuan can also be used as the agent of peace. Apart from the notion that political behavior exercised by Muslim Papuan leaders in the political arena is a defense mechanism, it also can be exploited to other directions. Identity commonalities of Muslim Papuan with the two parties; the Papuan nationalist and the majority Indonesian, and the high prestige of some elites in Papuan political society is an asset. It puts them in a perfect post as the agent of peace. Sayid Fadhal has also admitted in the interview by being the only Muslim in DAP he has been able to advocate the idea of Muslim Papuan as an inseparable part of the Papuan society. However, after having achieved the main goal of promoting Muslim Papuan voice in the society, the next goal of promoting peace has awaits." ${ }^{36}$

In general, there are at least four responsibilities that Islamic religious leaders carry out concerning the effort to minimize conflicts, i.e. 1) balancing national isuues dominated by politics of identity, 2) spreading the tolerant teachings of Islam that acknowledge and respect diversity and plurality, 3) running a counter-movement, especially from the Muslim community of local Papuan, towards the new 'radical' groups that intentionally promote massive Islamization, and 4) preserving traditions of indigenous Papuan Muslim descendants. These require Islamic religious leaders' good undertanding of not only the teachings of Islam and its relating current issues at local and national level, but also inter-relations between groups of the society. ${ }^{37}$ With

36 Nino Viartasiwi, "Holding on a Thin Rope: Muslim Papuan Communities as the Agent of Peace in Papua Conflict," Procedia Environmental Sciences, 17 (2013), pp. 860869.

37 The cohesion between religious communities and other parties of Papuan people can be seen factually from the shared vision of PTD (Papua Tanah Damai or Papua, the Land of Peace). This concept has been drawn up and promoted since 2003 by 
this capacity, any message towards the harmony in resolving religious conflict would be more effectively delivered to other parties (local "strongmen").

Traditional leaders, as local "strongmen", has also a strategic role in solving religious conflicts in Papua, especially in Jayapura. Despite lack of literatures that discuss it, in my opinion, the traditional leader as a peace knitter in dealing with a religious conflict is the same as the government in running the rules that have been formulated together. Traditional leaders in Jayapura are genealogically and sociologically attached to their own home community. Their responsibility is not limited to citizenship-related administration, but it also includes building and developing social life. Thus, in religious context, the attachment level of traditional leaders is not as significant as of the religious leaders in Jayapura. Accordingly, the most important role of the traditional leaders is to communicate the consensus that the society should be aware of tolerant values in their real life.

Social movement towards religious conflict resolution that is supported by structural-political power would be much more effective and efficient in achieving the goal. The last, but not least, is the goverment's role to ensure that every entities of the society, represented by religious and traditional leaders, upholds the intergroup mission of peace and commitment by utilizing available resources. It includes, but is not limited to, accomodating aspirations, facilitating dialogues, setting needed regulations, promoting the image of peaceful Papua to outside world.

\footnotetext{
various reliously-oriented organizations and religious leaders - the collaboration among them was even formally begun in 2000 - as a frame of reference concerning the development of Papua. They have supported the existance of MRP (Majelis Rakyat Papua) as cultural representatives that should not be politicized. Besides, they have confirmed their position out of MRP as a balancing power of critics and control, including in the development of sense of community in relation to conflict resolution. See Yulia Sugandi, "Conflict Analysis and Policy Recommendation on Papua" (Jakarta: Friedrichh Elbert Stiftung, 2008), available online at https://library.fes.de/pdffiles/bueros/indonesien/06394.pdf (accessed on 7 August 2020); Neles Tebay "Papua, the Land of Peace': The Interfaith Vision and Commitment for West Papua," Exchange, 36 (2007), pp 337-358.
} 


\section{The Local "Strongmen"'s Roles from the Perspective of Multi- Track Diplomacies}

In the last part of this article, I am going to explore more practical aspects, using the terminology of multi-track diplomacy, concerning the effective effort to reach religious harmony in Jayapura. This approach choice is for the two following reasons: first, the factual approach to Papuan society is through three tracks called Tiga Tungku (government, traditional leader, and religious leader); second, this theoretical framework are commonly used to resolve some conflicts in a certain country, or to develop economic comparative advantages owned by a certain country.

Louise Diamond and John McDonald define multi-track diplomacy as a part of conflict transformation theory that emphasizes various parties' involvement in resolving a conflict, and turn the conflict into sustainable peace. ${ }^{38}$ According to McDonald, nine tracks should be gone through to deal with a conflict resolution in a certain region, i.e. (1) government, (2) nongovernment/professional, (3) business, (4) private citizen, (5) research, training, and education, (6) activism, (7) religion, (8) funding, and (9) communication/media. ${ }^{39}$ The initiators of this theory also add twelve basic principles as listed in the following table.

Table 1.1 Twelve Principles of Multi-Track Diplomacy ${ }^{40}$

\begin{tabular}{llll}
\hline No & Aspect & \multicolumn{1}{c}{ Principle } & \multicolumn{1}{c}{$\begin{array}{c}\text { The Principle's } \\
\text { Contextualization in } \\
\text { Building Religious Harmony }\end{array}$} \\
\hline 1 & Relationship & $\begin{array}{l}\text { Building strong } \\
\text { interpersonal and } \\
\text { intergroup } \\
\text { relations } \\
\text { throughout the } \\
\text { fabric of society }\end{array}$ & $\begin{array}{l}\text { Encouraging attitude of } \\
\text { harmony establishment in the } \\
\text { inter-relationship of Tiga } \\
\text { Tungku according to their } \\
\text { respective roles, and building } \\
\text { good culture between amber and } \\
\text { komeng community }\end{array}$ \\
& & $\begin{array}{l}\text { Establishing the zone of } \\
\text { integrity, a kind of government }\end{array}$ \\
\hline 2 & $\begin{array}{l}\text { Long-term } \\
\text { commitment }\end{array}$ & ongoing an & \\
\hline
\end{tabular}

\footnotetext{
38 Ibid., p. 861.

39 See John W. McDonald, “The Institute for Multi-Track Diplomacy," Journal of Conflictology, 3, 2 (2012), pp. 66-70.

40 Ibid.
} 


\begin{tabular}{|c|c|c|c|}
\hline No & Aspect & Principle & $\begin{array}{c}\text { The Principle's } \\
\text { Contextualization in } \\
\text { Building Religious Harmony }\end{array}$ \\
\hline & & $\begin{array}{l}\text { commitment to } \\
\text { people and to } \\
\text { processes that may } \\
\text { take years to come } \\
\text { to fruition }\end{array}$ & $\begin{array}{l}\text { program, towards religious } \\
\text { harmony as intercultural glue in } \\
\text { Papuan society }\end{array}$ \\
\hline 3 & $\begin{array}{l}\text { Cultural } \\
\text { synergy }\end{array}$ & $\begin{array}{l}\text { Respecting the } \\
\text { cultural wisdom of } \\
\text { all the parties and } \\
\text { welcoming the } \\
\text { creative } \\
\text { interaction of } \\
\text { different cultural } \\
\text { ways }\end{array}$ & $\begin{array}{l}\text { Continuously conducting } \\
\text { dialogue, for example, in } \\
\text { organizing a celebration of a } \\
\text { religious event, like what have } \\
\text { been widely held in Jayapura } \\
\text { since the last few years }\end{array}$ \\
\hline 4 & Partnership & $\begin{array}{l}\text { Modeling } \\
\text { collaborative } \\
\text { process by } \\
\text { partnering with } \\
\text { local parties and } \\
\text { with other } \\
\text { institutions and } \\
\text { coalitions }\end{array}$ & $\begin{array}{l}\text { Building relationship with all } \\
\text { parties, including media, to } \\
\text { promote societies' recognition } \\
\text { for the religiosity of Papuan } \\
\text { using peace journalism, } \\
\text { especially Jayapura society }\end{array}$ \\
\hline 5 & $\begin{array}{l}\text { Multiple } \\
\text { technologies }\end{array}$ & $\begin{array}{l}\text { Utilizing a variety } \\
\text { of technologies, as } \\
\text { appropriate, and } \\
\text { creating new } \\
\text { methods, as } \\
\text { needed, to meet } \\
\text { the unique needs } \\
\text { of each situation }\end{array}$ & $\begin{array}{l}\text { Using social media and other } \\
\text { products of technologies to } \\
\text { communicate the diversity and } \\
\text { the values of religiosity that } \\
\text { Papuan society upholds }\end{array}$ \\
\hline 6 & Facilitation & $\begin{array}{l}\text { Assisting parties in } \\
\text { taking } \\
\text { responsibility for } \\
\text { their own dreams } \\
\text { and destiny }\end{array}$ & $\begin{array}{l}\text { Building a common dream of } \\
\text { the betterment of Papuan } \\
\text { society, either in the national or } \\
\text { global level }\end{array}$ \\
\hline
\end{tabular}




\begin{tabular}{|c|c|c|c|}
\hline No & Aspect & Principle & $\begin{array}{c}\text { The Principle's } \\
\text { Contextualization in } \\
\text { Building Religious Harmony }\end{array}$ \\
\hline 7 & Empowerment & $\begin{array}{l}\text { Helping people } \\
\text { become } \\
\text { empowered agents } \\
\text { of change and } \\
\text { transformation } \\
\text { within their } \\
\text { societies }\end{array}$ & $\begin{array}{l}\text { Continuously making efforts in } \\
\text { developing education, } \\
\text { empowering societies, } \\
\text { strengthening their economic } \\
\text { power via educational } \\
\text { institution, social organization, } \\
\text { and any other elements that } \\
\text { have been well accepted by } \\
\text { Papuan society }\end{array}$ \\
\hline 8 & Action research & $\begin{array}{l}\text { Learning from all } \\
\text { that we do and } \\
\text { sharing that } \\
\text { learning with } \\
\text { others }\end{array}$ & $\begin{array}{l}\text { Conducting researches and } \\
\text { development in collaboration } \\
\text { with either higher educational } \\
\text { institution or government } \\
\text { organization }\end{array}$ \\
\hline 9 & Invitation & $\begin{array}{l}\text { Entering the } \\
\text { system where } \\
\text { there is an } \\
\text { invitation and an } \\
\text { open door }\end{array}$ & $\begin{array}{l}\text { Having an attitude of openness } \\
\text { between indigenous Papuan } \\
\text { and other parties of Papuan } \\
\text { society }\end{array}$ \\
\hline 10 & Trust & $\begin{array}{l}\text { Building } \\
\text { relationships of } \\
\text { mutual trust and } \\
\text { caring within the } \\
\text { system }\end{array}$ & $\begin{array}{l}\text { Building the value system of } \\
\text { mutual trust in all levels of } \\
\text { Papuan society's life }\end{array}$ \\
\hline 11 & Engagement & $\begin{array}{l}\text { Acknowledging } \\
\text { that once we enter } \\
\text { a system we } \\
\text { become a unique } \\
\text { part of it: an } \\
\text { engaged, caring, } \\
\text { and accountable } \\
\text { partner }\end{array}$ & $\begin{array}{l}\text { Building a "Papuan common } \\
\text { identity" that adapts "friendly" } \\
\text { to the range of diversities in } \\
\text { society }\end{array}$ \\
\hline 12 & Transformation & $\begin{array}{l}\text { Catalyzing changes } \\
\text { at the deepest } \\
\text { level of beliefs, }\end{array}$ & $\begin{array}{l}\text { Pushing up levels of stages of } \\
\text { Papuan society's civilization; } \\
\text { from "the uncivilized" stigma }\end{array}$ \\
\hline
\end{tabular}




\begin{tabular}{lll}
\hline No Aspect & \multicolumn{1}{c}{ Principle } & $\begin{array}{c}\text { The Principle's } \\
\text { Contextualization in } \\
\text { Building Religious Harmony }\end{array}$ \\
\hline & $\begin{array}{l}\text { assumptions, and } \\
\text { values, as well as } \\
\text { behaviors and } \\
\text { structures }\end{array}$ & $\begin{array}{l}\text { to the more competitive and } \\
\text { contributive to the nation and } \\
\text { country of Indonesia }\end{array}$ \\
& \\
\hline
\end{tabular}

Brooke Patricia Galloway, citing Yilmaz's view, describes multitrack diplomacy as follows:

"Yilmaz analyzes the need for multi-track diplomacy and the
components to building peace after conflict. Yilmaz emphasizes
that there should be collaboration between government
representatives, community leaders, nongovernmental
organization leaders, business leaders, and leaders at the grassroots
level to provide input on a range of issues pertaining to designing
and implementing specific projects. To create a sustainable peace
agreement, tracks one, two and three need to work closely
together. Yilmaz (2009) claims that peacebuilding activities in
post-conflict settings include "strengthening the institutional base,
making a constitution or a new one, and establishing the rule of
law; strengthening security; economic reconstruction; as well as
national reconciliation,"... Through his analysis, Yilmaz also
found that strengthening the political level, or Track One, includes
bringing all tracks to the table since, “...dealing solely with the
government cannot foster political reconciliation, as the legitimacy
of the government is under question for some segments of the
society. ${ }^{41}$

From multi-track various definitions and principles above, I come to a conclusion that to resolve a conflict, three levels of handling are needed, whether in the level of leader or in other entities that share their interest in the conflict. The first level is at the top leader or community. This includes political leader, as well as of other countries that have shared-interest of the issue - but only if it is related to an

41 Brooke Patricia Galloway, "Perceptions of Peacebuilding and Multi-Track Collaboration in Divided Societies for a Sustainable Peace Agreement at the Political Level: A Case Study of Cyprus" (Unpublished Dissertation, Portland State University, 2011), p. 28. 
inter-country conflict. The second level is at the middle leader or community who share their life values with the middle groups. It could be level-2 political/governmental officials or a society's representatives who run an administrative position. The third level is at the grass-root leader or community. It could be religious leaders or NGO's who have certain motives to resolve the conflict.

Regarding conflict resolution, Islam itself has some principles to be applied. Ta'awun (cooperation), sabr (patience), ta'akbi (brotherhood), busn al-dhann (good assumption) are some basic principles from Islamic teaching that should be implemented for good conflict management practices. Besides, establishment of shura (council) to deliver an objective approach based on understanding of the Qur an and Hadith and appointment of a muslib (mediator) to facilitate mediation and discussion between conflicting groups or individuals are also needed as two essential entities along the process of managing conflicts. ${ }^{42}$ Islamic religious leaders, therefore, must be proactive in running these two roles while always trying to promote the principles and keep them bloom within their fellow communities. However, this conception, because of its generality, can be proposed to any cases of conflict, not limited to those concerning Islam. It is also substantively in line with the 12-dimension of multi-track diplomacies already mentioned.

Concerning religious conflict in Jayapura, the multi-track approach can be implemented through four decomposed stages. Firstly, it starts with the common conception of the problem faced by Papuan society by identifying the sources of conflict that are embodied in their daily life. I assume that the construct of conflict in Jayapura falls into national and global issues; to which researchers, reporters, and activists play their roles not based on the phenomenological beliefs of Papuan society. Those people build their interest on the basis of their sight that Papuan people are somewhere in a zone of retardation, and they need

42 Those principles are basically derived from the two main sources of Islamic teachings: the Qur'an and hadith. For example, please refer - but not limited - to surah al-Mā'idah: 2 for táannn, Aal-e-Imran: 200 for șabr, al-Hujurat: 12 for ḅusn al-dhann, alHujurat: 10 and an-Nisa': 36 for ta'akhi, al-Shura: 38 and aal-e-Imran: 159 for Shürä establishment, an-Nisa': 114 and 128 for muslih appointment. See Akram Abdul Cader, "Islamic Principles of Conflict Management: A Model for Human Resource Management," International Journal of Cross Cultural Management, 17, 3 (2017), pp. 345-363. This Cader's conception with its proposed framework is formulated to be more proactive as behavioral attributes that constitute organizational or social culture, rather than reactive actions concerning conflict resolution. 
a help from other national and international communities to end the conflict. Moreover, in local contestation, Papuan society tends to get misinformation about other religions. This retardation and misleads of information eventually turn Papuan Society to be more reactive to, rather than critically-reflective in ideological concerns.

At the second stage, this approach gets me a picture of agencies (and their roles) that will be involved in the structure of diplomacy. In my thoughts, on track one is the leaders at Papua Province level, the president of Indonesia, and global representatives. At this top level, the leaders joining in should carry strategic issues concerning how to grow and maintain religious harmony in Jayapura. At this rate, it is not compulsory to discuss the more practical aspects of the conflict. They need to speak out about strategic steps to overcome the "epidemic" religious conflict in Papua. In addition, these top leaders have to agree upon a log-term commitment to realization of sustainable networks on behalf of peace. Subsequently, no more contradictive and opposing statements or comments would come from any leaders about the situation of Papua.

On track two, such middle leaders as traditional leader, district head, regent/major, and other local government official leaders should also build a consensus/agreement, carry out socialization, empowerment, and effective dialogue among traditional leaders. The basic principle of this level is partnership and cultural strategies. At this level, the leaders usually have a good understanding of what the society needs actually. With this capacity, the middle leaders will be directly in touch with all the interests of indigenous groups, individuals, and migrants in any parts of Papuan region. Besides, they commonly have an ability to communicate with languages that ethnographically develop around their surroundings.

On track three stands grass-root leader as the bottom level leader. The elements of this group are those who play the issues, have a typical religious perspective, and subsequently trigger some conflict among Papuan society itself. They are of religious leaders, media reporters, NGOs, religious organization, new groups that react to their surrounding phenomena in accordance with their beliefs, and develop them to worrying issues.

At the third stage, issues reformulation and strategic alliances are carried out to build religious harmony in Jayapura. This requires action research, educational system building, and tolerant preaching between 
one another. Those all are not separable from its final objective: living in harmony. In more practical words, the identified issues from all the tracks are then tabulated to find a conclusion. After that, the policy makers, agencies, and other elements who have been engaged in the issue need to arrange collaboration with other entities at the bottom level. All stakeholders should build networks with the owners of public information to spread tolerant values and promote peaceful preaches, together with the religious leaders and NGOs. With this systematic and holistic effort, therefore, the advantages of a climate formed by religious harmony would be understood and finally experienced.

The final stage is about building cultural artefact of tolerance and harmony among Papuan society widely. This cultural artefact is presented as not only a physical building but also a set of attitude and example that is collectively run by Papuan society. They can see and feel how beautiful the tolerance is, without any discrimination between the indigenous and the migrant, the Muslims and the non-Muslims, and among different ethnic groups. I see that this artefact is not something impossible to build because Papuan society has historically strong religious values. They, once again, are anthropologically very obedient to their religious values. I agree with previous researchers who argue that the society can implant their prophetic values of their respective religions to dialogue, work on project together, and solve the problem of conflict based on those values without asking for other countries' help.

\section{Conclusion}

From the discussion above, it can be concluded that Islam and local "strongmen" have a great potential contribution to the realization of religious harmony in Jayapura. The society that has strong attachment to its local "strongmen" - with its good culture of tolerance to and respect for diversity including that of religion, and Islam as expressed moderately-inclusively by its religious leaders and followers are two main capitals to re-build and preserve commonalities in diverse religions in Papua. Although sometimes some other groups provoke and lead them to social or even political overreaction, with right conflict management and resolution that involve the Tiga Tungku the conflicting parties will be back to live peacefully side by side. They, including Islamic religious leaders, can be positioned as what in Islamic terminology is called shura (council) and muslib (mediator). This can be 
carried out by applying multi-track diplomacies in which the Tiga Tungku as the local "strongmen" in Papua have to proactively take part. The multi-track diplomacy can be used as a basis approach to change the mindset of the world and the local society about the prolonged conflict, that it can be resolved someday in the future.

However, any perspective, data, approaches, and practical aspects in building religious harmony in Papuan society cannot be generalized. This condition could be set comprehensively in Jayapura because of its modernization and long process of dynamization. Therefore, it maybe differs in other regions, for example, in West Papua where the proportion of its society is quite balance in terms of its political and social contestation. []

\section{References}

"Demonstrasi Pekerja Freeport" https://economy.okezone.com/ $\underline{\mathrm{read} / 2018 / 08 / 17 / 320 / 1937942 / \text { demo-eks-pekerja-freeport- }}$ bagaimana-kisah-sebenarnya (accessed on 2 December 2018)

"Indeks Kerukunan Umat Beragama di Papua Barat" http://www.satuharapan.com/read-detail/read/indeks-kerukunanumat-beragama-di-papua-barat-7284-persen (accessed on 26 March 2018).

"Papua menolak FPI dan HTI" https://www.papua.go.id/view-detailberita-4426/papua-tolak-fpi-dan-hti.html accessed on 23 March 2018

"Pembakaran Masjid di Papua" https://www.republika.co.id/berita/ nasional/hukum/15/07/17/nrmprs-ini-kronologispembakaran-masjid-di-tolikara (accessed on 18 April 2018)

"Penangkapan Tokoh Gerakan Papua Merdeka" https:// www.bbc.com/indonesia/indonesia-46454974 (accessed on 2 December 2018)

"Penolakan terhadap Kelompok Umar di Papua" https:// www.youtube.com/watch?v=Wm6aTIQCO40 (accessed on 18 April 2018) 
"Zona Kerukunan Beragama Kini Ada di Jayapura" https:// nasional.tempo.co/read/770572/jayapura-jadi-zona-integritaskerukunan-beragama (accessed on 26 March 2018)

al Hamid, Idrus. "Political Identity, Culture of Religious Plurality, and Implication in interaction of Jayapura Partnership." International Journal of Management and Administrative Sciences, 5, 10 (2018), pp. 18-29.

As'ad, Muh. "Kehidupan Keagamaan dan Budaya Masyarakat di Kota Jayapura Provinsi Papua." Jurnal al-Qalam, 20, 2 (2007), pp. 8598.

Bahar, M. Saeful. "Pola Interaksi Kyai-Bejingan dalam Pembangunan Demokrasi di Indonesia: Studi terhadap local-strongman dalam Pilkades di Kabupaten Bondowoso Jawa Timur". Unpublished Dissertation, Airlangga University, Surabaya, 2017.

Cader, Akram Abdul. "Islamic Principles of Conflict Management: A Model for Human Resource Management." International Journal of Cross Cultural Management, 17, 3 (2017), pp. 345-363.

Data of Papua BPS Office at 2016 https://papua. bps.go.id/ accessed on 26 March 2018.

Galloway, Brooke Patricia. "Perceptions of Peacebuilding and MultiTrack Collaboration in Divided Societies for a Sustainable Peace Agreement at the Political Level: A Case Study of Cyprus." Unpublished Dissertation, Portland State University, 2011.

Harriss, J., K Stoke and Olle Tomquist (eds). Politicizing Democracy: The New Local Politics of Democratization. London: Springer, 2004.

Hermawan, J. Budi. Gereja-Gereja di Papua; Menjadi Nabi di Tanah Sendiri. Jayapura: Sekretariat Keadilan dan Perdamaian Keuskupan Jayapura, 2002.

Kantor Kementerian Wilayah Agama Provinsi Papua, Majalab Damai; Jembatan Hati Nurani Umat, 16 (2017).

Marshall, A. J. and Bruce B. Beehler. The Ecology of Papua. Sydney: Periplus Edition Ltd, 2007.

McDonald, John W. "The Institute for Multi-Track Diplomacy." Journal of Conflictology, 3, 2 (2012), pp. 66-70.

Mu'ti, A. and Najib Burhani. "The Limits of Religious Freedom in Indonesia; With Reference to the First Pillar Ketuhanan Yang 
Maha Esa of Pancasila." Indonesian Journal of Islam and Moslem Societies, 9, 1 (2019), pp. 111-134.

Nuruddin, Sabara. "Kiprah Setengah Abad Yayasan Pendidikan Islam (Yapis) Papua; Membangun Harmoni Beragama melalui Dunia Pendidikan." al-Qalam, 24, 1 (2018), pp. 65-72.

Pamungkas, Cahyo. "The Contestation of Muslim and Special Autonomy in Papua." Religio: Jurnal Studi Agama-Agama, 5, 1 (2015), pp. 26-49.

Ramburu, Musa, Suwardono, Hasse J and Ridho al Hamdi. "The Construction of Muslim Identity Post Special Autonomy: The Study of Majelis Muslim Papua Existence." Epistemé: Jurnal Pengembangan Ilmu Keislaman, 13, 2 (2018), pp. 339-360.

Sidel, John T. "Bossism and Democracy in the Philippine, Thailand, and Indonesia; Towards an Alternative Framework for Study of Local Strongman." J. Harriss, K Stoke and Olle Tomquist (eds). Politicizing Democracy: The New Local Politics of Democratization. London: Springer, 2004.

Viartasiwi, Nino. "Holding on a Thin Rope: Muslim Papuan Communities as the Agent of Peace in Papua Conflict." Procedia Environmental Sciences, 17 (2013), pp. 860-869.

Waimbo, Denny Eris and Prapto Utomo, Dinamika Masyarakat Papua pada Era Otonomi Khusus. Jayapura: Universitas Cendrawasih Press, 2011. 